\title{
MISTERI ALLAH DALAM PANDANGAN PAULUS DAN IMPLIKASINYA BAGI PEMBERITAAN MASA KINI
}

\author{
Mira Marleni Pandie ${ }^{1}$ \\ sttjaffraymakassar@yahoo.co.id
}

\begin{abstract}
ABSTRAK
Sesuai dengan permasalahan yang ada, maka tujuan penulisan karya ilmiah ini adalah: Pertama,Untuk mengetahui makna misteri Allah dalam pandangan Paulus. Kedua,Agar pemberita Injil memahami misteri Allah sebagai dasar bagi pemberitaannya supaya mereka dapat melaksanakan tanggung jawab memberitakan Injil dengan benar.

Dalam penulisan karya ilmiah ini, penulis menggunakan metode penelitian literatur (Library research) yaitu menggunakan Alkitab, kamus, tafsiran dan bukubuku serta berbagai tulisan-tulisan yang terdapat dalam jurnal, yang berhubungan dengan pembahasan dalam karya ilmiah penulis.

Berdasarkan hasil uraian penulis dalam karya ilmiah tentang Misteri Allah Dalam Pandangan Paulusdan Implikasinya Bagi Pemberitaan Masa Kini, maka penulis dapat menarik kesimpulan sebagai berikut: Pertama, Rasul Paulus memnberitakan misteri Allah bukan berdasarkan pemahaman agama-agama misteri Yunani melainkan didasari oleh pemahamannya terhadap teologi Perjanjian Lama. Kedua, Paulus menyebut istilah misteri dalam pengertian bahwa Yesus Kristus adalah misteri Allah. Rahasia itu adalah kabar baik yang dinyatakan Allah dalam sejarah; rahasia itu adalah Allah sendiri, pusatnya ialah Kristus dan Paulus ditugaskan untuk memberitakannya terus-menerus. Ketiga, Pada masa kini, orang percaya yang telah terhisap dalam keselamatan Kristus juga memiliki tanggung jawab untuk memberitakan Yesus Kristus yang adalah misteri Allah sesungguhnya.
\end{abstract}

Kata kunci: Misteri Allah, Pandangan Paulus, dan Pemberitaan Masa Kini

\footnotetext{
${ }^{1}$ Mahasiswa Program Pascasarjana yang mengambil Mata Kuliah Teologi Perjanjian Baru.
} 


\section{PENDAHULUAN}

\section{Latar Belakang}

Penulis melayani di suatu tempat, ketika penulis mengungkapkan istilah misteri/rahasia maka beberapa anggota jemaat mempertanyakan dan meragukan istilah ini untuk disebutkan sebab latar belakang pola pemikiran mereka bahwa misteri adalah sesuatu yang berhubungan dengan penyembahan berhala. Atau istilah ini dipengaruhi oleh konsep dunia kafir. Jika mencermati dalam Alkitab, memang dalam terjemahan bahasa Indonesia tidak mencantumkan istilah misteri tetapi "rahasia." Namun dalam bahasa Yunani Kitab Injil bahkan dalam surat-surat Paulus menulis dengan mystērion atau misteri. Diakui bahwa istilah misteri ini dari dunia Yunani namun Pualus memakai istilah ini dengan menggunakannya dengan cara dan pemahaman yang sangat berbeda.

Di sisi lain, sekularisme sudah sedemikian menguasai masyarakat modern, dan salah satu ciri masyarakat sekularitas adalah ketidakacuhan dan ketidakterikatan terhadap berita Injil. Munculnya pluralisme agama juga menjadi tantangan tersendiri bagi pemberitaan masa kini. Apakah berita/rahasia Allah tetap diberitakan secara Alkitabiah ${ }^{2}$ atau dikompromikan dengan ajaran-ajaran lain yang tidak sesuai dengan apa kata Alkitab.

Bertolak dari permasalahan di atas, penulis distimulasi untuk menulis secara khusus membahas mengenai Paulus yang dapat tampil sebagai pemberita yang patut diteladani bukan saja dalam hidupnya tetapi secara khusus dalam pemberitaannya, dalam tulisan yang berjudul "Misteri Allah dalam pandangan Paulus dan implikasinya bagi pemberitaan masa kini" dengan harapan dapat menjawab permasalahanpermasalahan diatas.

\section{Rumusan Masalah}

Berdasarkan latar belakang pemaparan masalah yang telah dibahas di atas, penulis merumuskan masalah dalam bentuk pertanyaan. Adapun pertanyaan-pertanyaan yang dimaksud adalah sebagai berikut:

Pertama, Apa makna istilah misteri Allah dalam pandangan Paulus? Kedua,Bagaimana implikasi misteri Allah bagi pemberitaan masa kini?

${ }^{2}$ yang kita dengar dari mimbar Kristen dewasa ini sebagian besar tidak boleh disebut khotbah dalam arti sesungguhnya. Pembicaraan perkara politik, hal ihwal pengarang-pengarang yang tenar namanya, pokok yang hangat-hangat dan segala yang semacam itu, boleh dinamakan hanya pidato saja karena merupakan hasil pikiran si pembicara semata-mata; usaha seperti itu tidak boleh sekali-kali dinamakan berkhotbah dan orang yang melakukannya tidak berhak diberi gelar kehormatan pengkhotbah Injil selama ia masih saja menyampaikan berita itu di atas mimbar. William Evans, Cara Mempersiapkan Khotbah (Jakarta: BPK Gunung Mulia, 1983), 1. 


\section{Tujuan Penulisan karya ilmiah}

Berkenaan dengan rumusan masalah di atas, penulis merumuskan tujuan sebagai berikut:

Pertama,Untuk mengetahui makna misteri Allah dalam pandangan Paulus. Kedua,Agar pemberita Injil memahami misteri Allah sebagai dasar bagi pemberitaannya supaya mereka dapat melaksanakan tanggung jawab memberitakan Injil dengan benar.

\section{PANDANGAN PAULUS MENGENAI MISTERI ALLAH DAN IMPLIKASINYA BAGI PEMBERITAAN MASA KINI}

\section{Dasar Pemikiran Paulus}

Dalam hidup keagamaan, Paulus sangat taat kepada Hukum Taurat (Filipi 3:5) serta menjadi pekabar Yudaisme (Galatia 5:1l). Paulus menjunjung tinggi Perjanjian Lama sebagai Firman Allah, maka tidak heran bila pemikiran teologisnya berakar dalam teologi PL. Pemahaman Paulus tentang Allah, manusia, penebusan, perjanjian dan taurat serta eskatologis tidak dapat dipahami diluar Perjanjian Lama. ${ }^{3}$

\section{Misteri Allah dalam Perjanjian Lama}

Kata misteri dalam Perjanjian Lama berasal ari kata dasar rāz digunakan bersama-sama dengan kata pesar dan hanya terdapat dalam Kitab Daniel, dalam konteks Allah sebagai pengungkap misteri (Di surga ada Allah yang menyingkapkan rahasia-rahasia, Daniel 2:28). Terdapat indikasi adanya dua unsur penting yang menjadi sifat rāz yakni unsur tersembunyi dan dinyatakan atau diungkapkan. Dalam Perjanjian Lama dan Literatur Yahudi banyak terdapat latar belakang gagasan misteri. Walaupun terminologi itu memiliki makna baru dalam Perjanjian Baru, namun tidak seluruhnya asing dan gagasannya dikembangkan lebih lanjut dalam kitab Daniel. ${ }^{4}$

Mengenai hal ini, Ladd mengutip beberapa pendapat teolog:

Dalam Daniel ditemukan latar belakang penggunaan kata itu dalam

Perjanjian Baru. Allah berkenan memberi suatu mimpi kepada raja yang tidak bermakna apa-apa baginya dan makna itu hanya dapat diketahui melalui ilham dengan visi yang diberikan kepada Daniel, hamba Allah yang setia itu. Mimpi itu berhubungan dengan misteri 128.

${ }^{3}$ George Eldon Ladd, Teologi Perjanjian Baru 2 (Bandung: Kalam Hidup, 2002), 122.

${ }^{4}$ George Eldon Ladd, Teologi Perjanjian Baru I (Bandung: Kalam Hidup, 2010), 
maksud teologis Allah. Konsep rāz juga muncul dalam literatur Qumran. Kepada Guru Kebenaran, "Allah mengungkapkan semua misteri kata-kata hamba-hamba-Nya para nabi. Ini berarti bahwa Allah telah memberikan pencerahan khusus kepada Guru Kebenaran untuk menemukan makna yang benar dan tersembunyi dalam nubuat Alkitab. Misteri-misteri itu berkenaan dengan kejadian-kejadian yang diharapkan terjadi pada zaman akhir oleh masyarakat Qumran maupun dengan keputusan-keputusan ilahi yang tak terduga dan tak dapat di ubah dari Allah. ${ }^{5}$

Misteri itu tersembunyi dalam diri Allah, yaitu kebenarankebenaran ilahi yang merupakan rencana Allah dalam kekekalan. Misteri-misteri yang ditujukan oleh istilah rāz ini adalah penyingkapan tentang sejarah di dunia, dimana Allah akan membangun kerajaan-Nya di bumi. Penyingkapan ini bersifat progresif ${ }^{6}$ dan eskatologis yang dinyatakan kepada hamba-hamba-Nya untuk disampaikan kepada umat manusia. Dengan pemakaian istilah ini, jelas bahwa zr' (rāz) hanya berlaku untuk Allah sebagai revelear of misteries. Dialah alfa dan omega (Kel 3:41; Wahyu 1:8) yang mengetahui tentang permulaan dan akhir zaman termasuk nasib manusia, sehingga pada Dialah misteri yang sesungguhnya.

\section{Misteri Allah (musthêrion) dalam Perjanjian Baru}

Istilah Yunani misteri adalah musthêrion berasal dari kata dasar mustes digunakan 28 kali dalam Perjanjian Baru yang berarti rahasia, arti

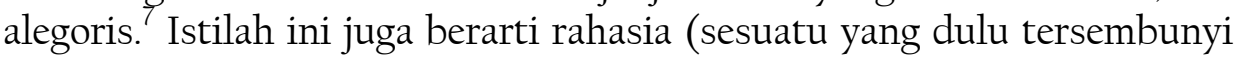
tetapi sekarang dinyatakan). ${ }^{8}$ Secret, secret teaching, mystery with reference to something previously unknown but now revealed (Mk 4:11; Rom 11:25; I Cor 2:7; 13:2; 15:51; Eph 3:3, 9; Col 1:26; 4:3, Rv 10:7). ${ }^{9}$ Menurut pemahaman Köstenberg: The primary denotation of mustherion, however was that of a secret

\footnotetext{
${ }^{5}$ Ibid.

${ }^{6}$ band. Millard Erickson, Consince Dictionary Of Christian Theology (Grand Rapids: Baker Book House, 1986), 143: A reference to the doctrine that later relevation is built upon carier relevation thus it contains truth which were not known before.

${ }^{7}$ Hasan Sutanto, Perjanjian Baru Interlinear Yunani - Indonesia dan Konkordansi Perjanjian Baru Jilid I (Jakarta: LAI, 2007), 528.

${ }^{8}$ Barclay M.Newman Jr. Kamus Yunani Indonesia (Jakarta: BPK Gunung Mulia, 2004), 110 . , Bible Works 7 Greek LXX/BNT
} 
knowledge of the ineffable, incomprehensible, impenetrable, "divine" a knowledge whice was reserved for religious initiates. ${ }^{10}$

Makna istilah musthêrion dalam bahasa Yunani kuno ialah sesuatu yang tersembunyi atau rahasia dalam bentuk jamak ta mustêria menunjuk pada upacara agama rahasia Yunani yang hanya dipatuhi anggotanya. Akar katanya ialah muô, mengatupkan mulut atau memejamkan mata (Latin mutus). Dalam PB arti musthêrion ialah rahasia ilahi yang sedang dinyatakan, atau bahkan sudah dinyatakan Allah kepada manusia melalui Roh-Nya."

Dalam Kitab-kitab Injil musthêrion terdapat dalam Markus 4:11; Matius 13:1l (jamak); Lukas 8:10, yang mengacu kepada Kerajaan Allah. Pengetahuan akan kerajaan ini, justru karena itulah "Kerajaan Allah" diberikan kepada beberapa orang saja. Karena itu rahasia tak diungkapkan bagi orang luar (exô) tapi tersembunyi dalam bentuk perumpamaan. ${ }^{12}$ Donald Guthrie berpendapat bahwa alasan mengapa Yesus menggunakan perumpamaan terkenal dalam perikop diatas terkenal sulit, sebab seolah-olah menyatakan bahwa perumpamaan dimaksudkan untuk mengaburkan kebenaran dari mata masyarakat umum. Tetapi menurut Guthrie, pemahaman ini keliru, kenyataan bahwa sejumlah orang tidak memahami kerajaan itu cocok dengan apa yang sudah dikatakan tentang kewargaan Kerajaan. Kerajaan itu menuntut sikap yang mau mendengarkan, suatu hasrat untuk menyingkapkan arti sebenarnya dari perumpamaan, suatu tekad untuk menaatinya. Yesus sangat menekankan nilai kerajaan. Nilai kerajaan itu demikian tinggi sehingga orang harus rela menjual segala sesuatu untuk memilikinya (Mat 13:44-46). Cara Yesus sendiri memahami Kerajaan memperlihatkan betapa kuatnya gagasan kerajaan dalam misi-Nya, sekalipun hal ini merupakan rahasia bagi pendengar-Nya. Yesus yakin bahwa kerajaan itu bukan hanya hadir masa kini, melainkan juga akan berhasil maju sampai puncaknya, namun ini tidak menghalangi-Nya untuk dengan tegar menghadapi kesengsaraan-Nya. Kematian Yesus merupakan bagian penting dari misi-Nya untuk menghadirkan kerajaan. $^{13}$

\footnotetext{
${ }^{10}$ Andreas J. Köstenberg, The Mistery Of Christ And The Church Head \& Body, One Flash; dalam Douglas Moo; Trinity Journal, (USA: Trinity Evangelical Dinity School, 1990), 80.

${ }^{11}$ J.D. Douglass, Ensiklopedi Alkitab Masa Kini Jilid II M-Z (Jakarta: YKBK, 2008), 290.

${ }^{12}$ Ibid. 291.

${ }^{13}$ Donald Guthrie, Teologi Perjanjian Baru 2 (Jakarta: BPK Gunung Mulia, 2011), $37-39$.
} 
Dalam pengajaran Yesus tentang kerajaan terutama nyata dalam perumpamaan-perumpamaan tentang kerajaan Allah dengan alasan untuk menyampaikan makna rahasia kerajaan. Bagaimanapun denotasi yang terutama tentang musthêrion adalah sebagai suatu pengetahuan rahasia yang terlalu suci untuk dikatakan. Dalam hal ini tidak dapat dimengerti dan tidak dapat ditembusi. Ini adalah suatu pengetahuan ilahi yang telah disediakan untuk permulaan religius. Menurut Liefeld, konsep dasar mysterion adalah rencana Allah dimana Allah bekerja secara bertahap dalam sejarah manusia melalui gereja dari penciptaan sampai pada akhir. ${ }^{14}$

\section{Misteri Allah (musthêrion) Dalam Pandangan Paulus}

Dalam surat-surat Paulus, kata ini dipakai sebanyak 21 kali. Paulus menggunakan istilah ini dengan latar balakang pemahamannya terhadap Perjanjian Lama. Disini penulis secara khusus memusatkan perhatian pada arti rahasia dalam Surat Kolose. Alkitab secara khusus menyebut Yesus Kristus sebagai yang terutama dalam pusat sejarah penebusan, sebagai rahasia Allah (Kol 2:2). Kolose 1:27-27 menyingkapkan beberapa hal tentang rahasia ini:

"yaitu rahasia yang tersembunyi dari abad ke abad dan dari turunan ke turunan, tetapi yang sekarang dinyatakan kepada orang-orang kudus-Nya. Kepada mereka Allah mau memberitahukan betapa kaya dan mulianya rahasia itu di antara bangsa-bangsa lain, yaitu Kristus ada ditengah-tengah kamu, Kristus yang adalah pengharapan akan kemuliaan. Dalam Terjemahan Yunani: musthêrion to apokekrummenon apo tôn aiônôn kai apo tôn geneôn nuni de ephanerôthê tois agiois autou ois ethelêsen o Theos gnôrisai ti to ploutos tes doxês tou musthriêou toutou en tois ethnesin o estin Cristos en humin ê elpis tês doxês

\section{Rahasia Ini Telah Di Sembunyikan}

Abraham Park berpendapat bahwa kata rahasia dalam bahasa Yunani adalah musthêrion menunjuk pada sebuah fakta yang belum tersingkap atau fakta yang tidak bisa diketahui dari luar karena telah disembunyikan. Kata apokekrummenon adalah the prefect passive form (pasif selesai) dari apokruptō dan menyingkapkan bahwa Allahlah yang menyembunyikan rahasia tersebut. ${ }^{15}$ Untuk itu misteri/rahasia ini tidak dapat dimengerti oleh hikmat dan kemampuan manusia; rahasia ini

${ }^{14}$ Liefeld Luku, The Expositor's Bible Commentary, 8 (Grand Rapids: Zondervan Publishing House, 1984), 906.

${ }_{15}$ Abraham Park, Pertemuan Yang Terlupakan Seri 2, (Jakarta: Grasindo dan Yayasan Damai Sejahtera Utama, 20011), 27. 
hanya dapat dimengerti pada saat Allah menyingkapkannya. Misteri ini bukanlah misteri yang terdapat dalam agama-agama misteri Yunani yang mana dalam dunia Hellenistik misteri-misteri dianggap sebagai agama negara, dalam pengertian menjadi agama pemujaan penduduk yang terkenal, yakni Demeter, dewi kesuburan, Dionysus (pemujaan kepada dewa) ${ }^{16}$ menceritakan tentang dewa-dewa yang turun dalam bentuk manusia dan tentang dewa-dewa penyelamat yang dipanggil "tuhan." Ataupun misteri dalam filosofi yang dimulai oleh Plato dengan idea sebagai dasar filsafatnya, misteri yang diperoleh dengan perantaraan akal manusia yang abstrak.

Menurut George Ladd:

Rahasia dalam Perjanjian Baru, khususnya dalam tulisan Paulus telah menjadi istilah teknis yang dihubungkan dengan wahyu ilahi. Latar belakangnya bukan berasal dari upacara ritual agama-agama Helenistik esoteric yang hanya diketahui oleh orang-orang tertentu dari ajaranajaran yang hanya diungkapkan kepada mereka yang baru masuk suatu sekte dimana mereka mencapai tingkat kesempurnaan (teleios) atau kerohanian yang tinggi (pneumatikos). Latar belakangnya berasal dari konsep Perjanian Lama tentang Allah yang mengungkapkan rahasia-rahasia-Nya kepada manusia yang kemudian dikembangkan dalam tulisan Yahudi. ${ }^{17}$

Rahasia ini adalah rahasia besar bagi pekerjaan sejarah penebusan dari Allah yang diberitakan kepada umat-Nya melalui wahyu. Rahasia ini adalah kehendak Allah (I Kor 2:7; 4:1; Ef 3:3). Rahasia itu terkandung dalam rencana kekal Allah dan tersembunyi dalam Dia (Efesus 3:9), ditentukan sebelum dunia dijadikan (I Kor 2:7) dan disebut sofia (hikmat) Allah yang berabad-abad lamanya terselubung dari pengertian manusia menunggu penyataannya (I Kor 2:8; Roma 16:25).

Rahasia ini telah disembunyikan dari abad ke abad dan dari turunan ke turunan (Kol l:26). Bentuk jamak dari kata abad dalam bahasa Yunani adalah aiōn yang berarti kekal dan bentuk jamak dari kata keturunan dalam bahasa Yunani adalah genea, yang berarti keturunan. Oleh karena itu kalimat "dari abad ke abad dan dari turunan ke turunan" memiliki arti dari kekekalan dan setiap generasi yang berkesinambungan artinya dinyatakan dalam sejarah.

${ }^{16}$ Andreas J. Kostenberg, The Mistery Of Christ and The Church Head \& Body, One Flesh; dalam Douglas Moo, Trinity Journal, (USA: Trinity Evangelical Dinity School, 1990), 80. 111.

${ }^{17}$ George Eldon Ladd, Teologi Perjanjian Baru 2, (Bandung: Kalam Hidup, 2002) 


\section{Rahasia Ini Dinyatakan}

Kolose 1:26 "...tetapi yang sekarang dinyatakan kepada orang-orang kudus-Nya." Ungkapan ini berarti bahwa rahasia Allah yang telah disembunyikan telah dinyatakan secara luar biasa dan rahasia pekerjaan penyelamatan lewat Yesus Kristus hanya dapat dimengerti sewaktu Allah menyatakannya kepada orang-orang yang percaya kepada-Nya. Misteri ini diberitakan kepada semua orang, walaupun hanya dipahami oleh mereka yang percaya. ${ }^{18}$ Fakta penyataan melalui para rasul dikemukakan secara jelas dalam surat Efesus. Rahasia Kristus yakni maksud ilahi yang terlaksana dalam peristiwa kedatangan Yesus Kristus (Kol 4:3), yang tidak dinyatakan kepada manusia generasi lampau namun sekarang telah dinyatakan kepada rasul dan nabi kudus oleh Roh Allah (Ef 3:5). Wahyu yang dinyatakan kepada para rasul dan nabi ini tidak bermaksud menciptakan kelompok manusia yang elit rohani yang mengatasi orang-orang percaya lain melainkan rasul-rasul itu adalah penerima wahyu dengan tujuan agar mereka boleh menyatakan apa isinya tugas penyelenggaraan rahasia yang telah berabad-abad tersembunyi dalam Allah (Efesus 3:8).

Jadi Paulus dapat pula berkata secara konsisten bahwa rahasia yang tersembunyi selama berabad-abad sekarang telah dinyatakan kepada orang-orang suci-Nya (Kol 1:26), rasul-rasul adalah para penyelenggara (oikonomia) rahasia-rahasia Allah (I Kor 4:1) dan telah menerima jabatan ilahi ini untuk memberitakan Firman Allah.

\section{Isi Rahasia}

Rahasia yang dimaksud oleh Paulus adalah Kristus. Paulus memahami "misteri-misteri" sebagai rahasia yang akan diungkapkan, maksud-maksud ilahi yang tersembunyi dari manusia selama berabadabad tetapi akhirnya diungkapkan kepada semua orang melaui wahyu (Roma 16:25-26). Dalam Pandangan Paulus (musthêrion) adalah the fulfillment of God's promises made in the Old Testament. Ini merupakan penggenapan janji Tuhan kepada kaum Israel. ${ }^{19}$ Hal yang paling mendasar bagi Paulus dalam memahami seluruh konsep misteri dalam Perjanjian Lama adalah pada peristiwa Kristofani Misteri Kristus dalam Kisah Para Rasul 9:3-19 (band. Gal 1:12).

Disini Allah menyingkapkan misteri yang tersembunyi kepada Paulus. Misteri ini merupakan panggilan Kristus bagi Paulus untuk menjadi saksinya yaitu memberitakan Injil kepada segala bangsa. Penekanan yang paling mendasar bila berbicara tentang istilah musth,rion 2010) 122 .

${ }^{18}$ George Eldon Ladd, Teologi Perjanjian Baru 1, (Bandung: Kalam Hidup,

${ }^{19}$ C.E.B. Cranfield, Romans: A Shorter Commentary (Grand Rapids; Wm. B. Eerdmans Pub. Co, 1985), 384. 
dalam surat-surat Paulus, yaitu Kristus adalah misteri milik Allah, yang disingkapkan melalui Yesus Kristus yang pernah dinyatakan kepada Paulus dalam peristiwa Kristofani. Yesus Kristus inilah misteri Allah yang sebenarnya yang telah diberitakan terus-menerus oleh Paulus kepada jemaat-jamaat yang dilayaninya. Istilah memberitakan terusmenerus dapat dicermati dari Kolose 1:28, dengan penggunaan istilah yang diterjemahkan memberitakan, dengan bentuk (verb indicative present active) merupakan kata kerja dan menunjukkan suatu cara atau tujuan yang dilakukan terus menerus pada waktu yang sama dengan apa yang disebut dengan kata kerja induk kalimat.

Meskipun ada yang menganggap bahwa pemakaian (musthêrion) oleh Paulus dipengaruhi oleh konsep agama misteri Yunani, namun para ahli telah menyelidiki bahwa konsep Perjanjian Lama lebih konsisten yakni konsep tentang penyingkapan rahasia-rahasia Allah kepada manusia yang jauh telah berkembang dalam literatur Yahudi. ${ }^{20}$ Ketika menangani masalah-masalah yang muncul dalam gereja Korintus, Paulus menjelaskan bahwa rahasia sebagai wahyu itu mencapai tiga unsur: fakta dalam Yesus Kristus yang tersalib, kebangkitan dan pemuliaan-Nya sebagai Tuhan yang telah ditinggikan serta makna penebusan Yesus Kristus yang telah mati, bangkit dan naik ke surga. ${ }^{21}$

Bagi Paulus Yesus Kristus adalah arti dari misteri sesungguhnya sehingga kabar baik yang disampaikan Paulus adalah kabar yang berpusat pada Yesus Kristus yang adalah Allah yang berinkarnasi, salib, penebusan. Misteri yang diberitakan Paulus adalah rahasia tentang bagaimana Allah memuliakan hamba-Nya (Kisah 3:13) dengan menjadikan Dia Kristus yaitu pemimpin dan juruselamat (Kisah 5:1) yang telah lama dinantikan dunia. Yesus Kristus yang adalah Allah menderita sampai mati di kayu salib untuk menebus hidup manusia yang terkutuk. Rahasia berpusat pada dan dinyatakan dalam diri Tuhan Yesus Kristus dan kematian-Nya untuk memperdamaikan manusia dengan Allah (2 Kor 5:18).

Misteri ini adalah bahwa pengorbanan Yesus Kristus adalah klimaks dari dunia. Pengorbanan Yesus Kristus adalah faktor penentu dalam sejarah dan nasib manusia. Pengorbanan Kristus di atas kayu salib menjangkau batas-batas dunia yang terjauh dan terlepas dari suku apapun, keistimewaan pribadi atau hak individu. Pengorbanan Kristus di salib adalah klimaks bagi iblis sebab disanalah iblis hancurkan/dibuat

\footnotetext{
${ }^{20}$ Andreas J. Köstenberg, The Mistery Of Christ And The Church Head \& Body, One Flash; dalam Douglas Moo; Trinity Journal, (USA: Trinity Evangelical Dinity School, 1990), 80-81.

${ }^{21}$ George Eldon Ladd, Teologi Perjanjian Baru 2, (Bandung: Kalam Hidup, 2002) 112.
} 
menjadi sia-sia. ${ }^{22}$ Setiap orang berdosa yang datang kepada Yesus Kristus yang tersalib dengan iman yang tulus akan dilepaskan dari tipu muslihat dan kekuasaan iblis (Kolose 1:13). Mengenai hal ini Donald Guthrie mengemukakan:

Dalam Kolose 4:1l Paulus berbicara tentang teman sekerja untuk kerajaan Allah, dengan menganggap bahwa kerajaan itu merupakan tujuan dari pekerjaan pekerjaan penginjilannya. Dalam hal ini istilah kerajaan nampaknya mencakup segala tindakan Allah demi kepentingan manusia. Tetepi ini harus dipahami dalam kaitannya dengan Kolose 1:13-14, yang mengatakan bahwa Allah telah "memindahkan kita ke dalam Kerajaan Anak-Nya yang kekasih; di dalam Dia kita memiliki penebusan yaitu pengampunan dosa." Kita dipindahkan dari lingkungan kuasa kegelapan. Dengan demikian, orang-orang percaya menjadi milik kuasa yang lain jenisnya, yaitu lawan dari keadaan mereka sebelumnya. Disini kita bertemu dengan penaklukan kuasa-kuasa iblis, yang sama dengan pengusiran setansetan dalam kitab-kitab Injil Sinoptik. Paulus menggunakan cara pengungkapan yang berbeda tapi dasar pemikirannya sama. ${ }^{23}$

Karya Kristus di atas kayu salib adalah klimaks bagi semua orang. Bagi manusia berdosa yang menyadari akan dosanya dan berbalik pada Kristus serta percaya kepada-Nya sebagai Juruselamat pribadi, berarti kehidupan kekal dan keselamatan kekal; namun bagi mereka yang berpaling dari salib Kristus dengan ketidakpercayaan dan kebanggaan berarti kematian kekal.

Dalam I Koritus 2:7 Paulus menyatakan bahwa "Tetapi yang kami beritakan ialah hikmat Allah yang tersembunyi dan rahasia yang sebelum dunia dijadikan, telah disediakan Allah bagi kemuliaan kita." Rasul Paulus menganggap sebagai suatu berita besar. Ada ahli yang menduga bahwa rahasia itu mungkin rasul Paulus secara langsung atau tidak langsung peroleh dari seorang nabi. Mereka menunjuk kepada Kisah Rasul 1l:27; yang menceritakan tentang nabi Agabus yang oleh "Roh Kudus" meramalkan bahwa seluruh dunia akan ditimpa bahaya kelaparan. Dalam Kisah 21: 10-14 nabi Agabus yang sama datang menemui Paulus dan kawan-kawannya di Kaisarea dan oleh pimpinan Roh Kudus mengatakan kepada Paulus bahwa dirinya akan di tangkap di Yerusalem. Menurut mereka Rasul Paulus menghormati nabi-nabi yang berkata-kata dengan pimpinan Roh Kudus (band. I Kor 14: 29,37), rahasia yang Paulus sebut dalam I Korintus kata mereka mungkin berasal dari seorang nabi dan perkataan nabi ini rasul Paulus anggap

\footnotetext{
${ }^{22}$ Leon Morris, Salib Kristus (Malang: SAAT, 2000) 46-47.

${ }^{23}$ Donald Guthrie, Teologi Perjanjian Baru 2 (Jakarta: BPK Gunung Mulia, 2011), 42
} 
sebagai perkataan Yesus sendiri. ${ }^{24}$ Mencermati hal ini Abineno menegaskan bahwa semua ini hanya dugaan saja sebab dalam tulisannya, kesaksian-kesaksian Paulus mempunyai warna tersendiri. ${ }^{25}$

Paulus melanjutkan dengan "Kepada mereka Allah mau memberitahukan betapa kaya dan mulianya rahasia itu diantara bangsabangsa lain yaitu Kristus ada ditengah-tengah kamu, Kristus yang adalah pengharapan akan kemuliaan (Kolose 1:27)."

Keselamatan ilahi yang telah disediakan tersembunyi kepada manusia berabad-abad lamanya kini telah sampai pada waktu penyataan dimana Allah menyatakan di dalam Yesus Kristus dan diberitakan kepada semua bangsa.

Dengan demikian pasti bahwa pengharapan dan hidup baru dalam Kristus tersedia bagi orang Yahudi dan non- Yahudi tanpa pembedaan (Gal 3:28; Ef 3:8; Kol 1:27). Roma 2;28-29 menyatakan bahwa yang disebut Yahudi adalah orang Yahudi karena hubungan darah, tetapi orang Yahudi sejati menunjuk kepada orang-orang beriman yang percaya kepada Yesus Kristus dengan mengatasi batas-batas hubungan darah (Gal 3:7-9; 26-29). Jadi, tidak ada orang Yahudi atau orang Yunani, tidak ada hamba atau orang merdeka, tidak ada laki-laki atau perempuan, semuanya telah menjadi satu dalam Yesus Kristus (Gal 3:28). kayu salib telah menjadi kekuatan Allah yang menyelamatkan setiap orang yang percaya, baik bangsa Yahudi maupun bangsa-bangsa lain. Kemuliaan kepenuhan yang diterima oleh bangsa-bangsa lain adalah rahasia yang mulia.

\section{Sifat Rahasia}

Menurut kitab Injil Sinoptik, rahasia kerajaan harus dimengerti secara rohani. Pengertian ini dipertahankan Paulus tatkala memandang misteri Kristus (khususnya ialah non Yahudi turut menjadi ahli waris kerajaan) sebagai rahasia dinyatakan kepada rasul dan nabi oleh Roh (enpneumati, Ef $3: 5$ band. I Kor 13:2; 14:2). Makna ilahi rahasia itu dimengerti melalui penyataan dan pengertian rohani. Kerajaan itu bukan soal makanan dan minuman, melainkan soal kebenaran dan damai sejahtera dan sukacita dalam Roh Kudus (Roma 14:17). Hal ini dengan jelas koreksi terhadap orang-orang yang keliru membayangkan bahwa kerajaan itu berhubungan dengan soal pantangan-pantangan makanan. Dalam I Korintus 4:20 Paulus menolak pemahaman bahwa kerajaan adalah soal perkataan, dalam hal ini menentang orang-orang yang bersandar pada kefasihan berbicara, hikmat dunia. Orang-orang di

\footnotetext{
${ }^{24}$ J.L.Ch. Abineno, Manusia Dan Sesamanya Di dalam Dunia (Jakarta: BPK Gunung Mulia, 2003), 190.

${ }^{25}$ Ibid.
} 
Korintus lebih condong pada ajaran pneumatic gnostik yang mengemukakan bahwa mereka memiliki hikmat yang menjamin keselamatan yang sempurna (I Korintus 3:1) sehingga penganutnya menunjukkan sikap acuh terhadap daging. ${ }^{26}$ Dalam Injil Sinoptik ditemukan ucapan Yohanes 3:5 yang menjelaskan bahwa "sesungguhnya jika seorang tidak lahir dari air dan Roh, ia tidak dapat masuk ke dalam Kerjaan Allah." Peran Roh dalam kelahiran kembali memperlihatkan dengan jelas bahwa ini adalah suatu pekerjaan ilahi. Menurut Guthrie "Penyataan ini membuang gagasan Kerajaan sebagai pekerjaan manusia. ${ }^{27}$ Selanjutnya Guthrie mengemukakan:

Dalam Yohanes 18:33 Pilatus, dalam percakapannya dengan Yesus bertanya "Engkau inikah Raja orang Yahudi? Pertanyaan ini menggairahkan Yesus untuk menegaskan bahwa kerjaan-Nya bukan dari dunia ini (Yoh 18:36). Yesus kemudian menambahkan "Untuk itulah Aku lahir dan untuk itulah Aku datang ke dalam dunia ini, supaya Aku memberi kesaksian tentang kebenaran (Yoh 18:37). Ini benar-benar merupakan pandangan rohani tentang kerajaan. ${ }^{28}$

\section{Mystērion Bersifat Eskatologis}

Rahasia yang dinyatakan dalam waktu, masih menantikan penyempurnaan dan penggenapan ilahinya dalam hidup kekal. Berkenaan dengan ini Ladd berpendapat:

Inti tesis kita adalah bahwa Kerajaan Allah adalah pemerintahan penebusan Allah yang secara dinamis giat untuk membangun pemerintahan-Nya di antara manusia dan bahwa kerajaan itu yang akan muncul sebagai suatu tindakan apokaliptis pada akhir zaman, telah datang ke dalam sejarah manusia di dalam pribadi dan misi Yesus untuk mengalahkan kejahatan, untuk melepaskan manusia dari kuasa kejahatan itu dan membawa mereka ke dalam berkat-berkat pemerintahan Allah. Kerajaan Allah mencakup duu masa yang penting yakni pemenuhan dalam sejarah dan penggenapan pada akhir sejarah. ${ }^{20}$

Kendati ada permasalahan aspek ganda dalam pemahaman Kerajaan Allah yang mana gagasan tentang kerajaan masa kini sangat di dukung oleh aliran liberal yang menekankan Yesus sebagai manusia biasa dalam dunia ini dan bagi mereka semua keterangan mengenai

${ }^{26}$ George Eldon Ladd, Teologi Perjanjian Baru 2 (Bandung: Kalam Hidup, 2002), 112.

${ }^{27}$ Donald Guthrie, Teologi Perjanjian Baru 2 (Jakarta: BPK Gunung Mulia, 2011), 40.

${ }^{28}$ Ibid.

${ }^{29}$ George Eldon Ladd, Teologi Perjanjian Baru I (Bandung: Kalam HIdup, 2010) 118. 
kerajaan pada masa depan menjadi tidak relevan. Di sisi lain bangkit aliran yang menekankan aspek eskatologis yang dipimpin oleh J. Weiss (1892) dan A. Schweitzer (1906). Penekanan Schweitzer pada aspek eskatologis mempengaruhi Bultmann yang menganggap Yesus sebagai seorang nabi apokaliptik yang mengharapkan kedatangan kerajaan itu dengan segera. ${ }^{30}$ Dalam hal ini penulis menyetujui pendapat Ladd yang didukung oleh Ronald Gutrie bahwa aspek masa kini dan masa akan datang mutlak perlu bagi pemahaman ajaran Yesus tentang kerajaan. Amanat Yesus ialah bahwa dalam diri dan misi-Nya Allah telah menerobos sejarah manusia dan telah menang atas kejahatan, walaupun penaklukan yang tuntas tidak akan terjadi sebelum akhir zaman. Kerajaan Allah tidak bisa dipisahkan dalam pelayanan dan pekerjaan Kristus; di dalam Dia apa yang secara mendasar merupakan aspek masa datang menjadi nampak dalam aspek masa kini. Intinya misi Kristus terjalin dengan kedatangan kerajaan Allah.

\section{Implikasi Untuk Pemberitaan Masa Kini}

Keselamatan yang Tuhan berikan kepada orang percaya secara khusus yang dipanggil untuk menjadi pemberita mempunyai maksud atau implikasi bagi mereka yang telah diselamatkan. Sebagai pemberita Injil, yang disampaikan Paulus terus menerus adalah misteri Allah yang adalah Yesus Kristus. Pemberita masa kini yang percaya bahwa telah diselamatkan oleh salib Kristus juga mesti melaksanakan tujuan utama panggilannya yakni memberitakan misteri Allah bukan hanya sewaktuwaktu melainkan terus-menerus dalam hal ini perlu meneladani berita Paulus agar konsisten dalam memberitakan tentang Yesus Kristus yang olehnya manusia beroleh keselamatan.

\section{KESIMPULAN}

Rasul Paulus memnberitakan misteri Allah bukan berdasarkan pemahaman agama-agama misteri Yunani melainkan didasari oleh pemahamannya terhadap teologi Perjanjian Lama

Paulus menyebut istilah misteri dalam pengertian bahwa Yesus Kristus adalah misteri Allah. Rahasia itu adalah kabar baik yang dinyatakan Allah dalam sejarah; rahasia itu adalah Allah sendiri, pusatnya ialah Kristus dan Paulus ditugaskan untuk memberitakannya terus-menerus.

Pada masa kini, orang percaya yang telah terhisap dalam keselamatan Kristus juga memiliki tanggung jawab untuk memberitakan Yesus Kristus yang adalah misteri Allah sesungguhnya.

\footnotetext{
${ }^{30}$ Donald Guthrie, Teologi Perjanjian Baru 2 (Jakarta: BPK Gunung Mulia, 2011), 31.
} 


\section{KEPUSTAKAAN}

Alkitab

Alkitab. Jakarta: Lembaga Alkitab Indonesia, 2010.

Buku-buku

Abineno, J.L. Ch. Manusia dan Sesamanya Di Dalam Dunia. Jakarta: BPK Gunung Mulia, 2003.

Cranfield, C.E.B. Romans: A Shorter Commentary. Grand Rapids: Wm. B. Eerdmans Pub.Co, 1985.

Douglass, J.D. Ensiklopedi Alkitab Masa Kini Jilid II M-Z . Jakarta: YKBK/OMF, 2008.

Erickson, Millard. Consince Dictionary Of Christian Theology. Grand Rapids: Baker Book House, 1986.

Evans, Williams. Cara Mempersiapkan Khotbah. Jakarta: BPK Gunung Mulia, 1983.

Guthrie, Donald. Teologi Perjanjian Baru 2. Jakarta: BPK Gunung Mulia, 2011.

Ladd, George Eldon. Teologi Perjanjian Baru 1. Bandung: Kalam Hidup, 2010. , Teologi Perjanjian Baru 2. Bandung: Kalam Hidup, 2002Luku, Liefeld. The Expositor' Bible Commentary 8. Grand Rapids: Zondervan Publishing House, 1984.

Morris, Leon. Salib Kristus. Malang: SAAT, 200.

Newman, Barclay Jr. Kamus Yunani Indonesia. Jakarta: BPK Gunung Mulia, 2004.

Park, Abraham. Pertemuan Yang Terlupakan Seri 2. Jakarta: Grasindo dan Yayasan Damai Sejahtera Utama. 2011

Sutanto, Hasan. Perjanjian Baru Interlinear Yunani-Indonesia dan Konkordansi Perjanjian Baru Jilid l. Jakarta: LAI, 2007.

\section{Referensi Dari Jurnal}

Andreas J. Kostenberg, "The Mistery Of Christ and the Church Head \& Body, One Flesh" Trinity Journal, 1990.

Referensi Dari CD Room , International Translator The Bible Works LLC, 7,0 